\title{
Faecal tumour M2 pyruvate kinase: a new, sensitive screening tool for colorectal cancer
}

\author{
PD Hardt", , S Mazurek², M Toepler ${ }^{3}$, P Schlierbach ${ }^{3}$, RG Bretzel', E Eigenbrodt ${ }^{2,4}$ and HU Kloer' \\ 'Third Medical Department and Policlinic, Giessen University Hospital, Justus-Liebig-University of Giessen, Rodthohl 6, Giessen 35392, Germany; ${ }^{2}$ nnstitute \\ of Biochemistry and Endocrinology, Veterinary Faculty, University of Giessen, Frankfurter Strasse 100, Giessen 35392, Germany; ${ }^{3}$ Medical Department \\ and Surgical Department of the Asklepios Clinic, Goethestrasse 4, Lich 35423, Germany
}

Proliferating cells, especially tumour cells, express a special isoenzyme of pyruvate kinase, termed M2-PK, which can occur in a tetrameric form with a high affinity to its substrate, phosphoenolpyruvate (PEP), and in a dimeric form with a low PEP affinity. In tumour cells, the dimeric form is usually predominant and is therefore termed Tumour M2-PK. The levels of Tumour M2-PK within tumours and in EDTA-plasma correlate with staging and the ability of the tumour cells to metastasise. Since most colorectal tumours grow intraluminally, it appeared interesting to determine whether Tumour M2-PK is detectable in the faeces of tumour patients. Stool samples were tested by ELISA from controls without colorectal cancer and colorectal cancer patients. Whereas Tumour M2-PK levels were low in the control group (mean value \pm s.e.m.: $3.3 \pm 0.4, n=144$ ), they were high in the case of colorectal cancer $(56.1 \pm 15.3, n=60)$. At a cutoff value of $4 \mathrm{U} \mathrm{ml}^{-1}$, the sensitivity was $73 \%$. TNM and Dukes' classification of the tumours revealed a strong correlation between faecal Tumour M2-PK levels and staging. The determination of Tumour M2-PK in faeces provides a new promising screening tool for colorectal tumours.

British Journal of Cancer (2004) 91, 980-984. doi: I0.1038/sj.bjc.6602033 www.bjcancer.com

Published online 13 July 2004

(c) 2004 Cancer Research UK

Keywords: tumour M2-PK; colorectal cancer; stool; tumour screening

One alteration consistently found during tumour formation, including gastrointestinal tumours, is the upregulation of glycolytic enzymes. This upregulation takes place at the RNA and protein level, as well as at the level of enzymatic activities (Durany et al, 1997; Eigenbrodt et al, 1997; Mazurek et al, 2000; Hegde et al, 2001; Atsumi et al, 2002; Birkenkamp-Demtroder et al, 2002; Williams et al, 2003). In addition, in the case of the glycolytic enzyme pyruvate kinase, a loss of the tissue-specific isoenzymes (L-PK in the liver, M1-PK in muscle and brain and R-PK in erythrocytes) and expression of the pyruvate kinase isoenzyme type M2 (M2-PK) is described in all tumours investigated thus far (Figure 1A) (Staal and Rijksen, 1991; Mazurek et al, 1997; Steinberg et al, 1999). The increase in M2-PK levels has been recorded by the determination of enzymatic activities, cellulose acetate electrophoresis, Western blotting and immunohistology (Reinacher and Eigenbrodt, 1981; Staal and Rijksen, 1991; Eigenbrodt et al, 1992; Mazurek et al, 2000). In healthy tissues, all isoenzymes of pyruvate kinase consist of four subunits whereby hybrids of the different forms can also occur (Saheki et al, 1978, 1979). Whereas in the epithelium of the upper gastrointestinal

*Correspondence: Dr PD Hardt;

E-mail: Philip.D.Hardt@innere.med.uni-giessen.de

* This work is dedicated to the memory of Professor Erich Eigenbrodt who died in June 2004. His fundamental research in tumour metabolism resulted in the development of tumour M2-PK tests and their introduction for clinical applications.

Received 30 December 2003; revised 20 May 2004; accepted 7 June 2004; published online 13 July 2004 tract (oesophagus and stomach) hybrids between M1 and M2 have been found, the lower gastrointestinal tract (jejunum, colon and rectum) is characterised by hybrids of L and M2-PK (Saheki et al, $1978,1979)$. In gastrointestinal tumours, only subunits of the type M2 are detectable and pyruvate kinase is mainly in the dimeric form (Mazurek et al, 2000). Therefore, the dimeric form of M2-PK has been termed Tumour M2-PK. The tetramer : dimer ratio of M2PK can be quantified by gel permeation, isoelectric focusing or by ELISA (Cerwenka et al, 1999; Schulze, 2000; Mazurek et al, 1997, 2001; Mazurek and Eigenbrodt, 2003). The upregulation of the M2PK protein is under the control of HIF-1 and ras, which are both consistently altered in gastrointestinal tumours (Kress et al, 1998; Mazurek et al, 2001; Nishikawa et al, 2002; Mazurek and Eigenbrodt, 2003). The tetramer: dimer ratio of M2-PK is under the control of several oncoproteins, such as $\mathrm{pp} 60^{\mathrm{v}-\text { src }}$ kinase, HPV16 E7 and A-Raf (Figure 1B) (Eigenbrodt et al, 1998b; Zwerschke et al, 1999; Le Mellay et al, 2002). Interestingly, pp60 ${ }^{\mathrm{c}-\text { src }}$ kinase and A-Raf are consistently altered in gastrointestinal tumours (Bolen et al, 1987; Iravani et al, 1998; Irby et al, 1999; Luckett et al, 2000; Dehm et al, 2001; Dhillon et al, 2003).

Determinations of Tumour M2-PK in EDTA-plasma samples of patients with gastrointestinal tumours revealed an upregulation of Tumour M2-PK in oesophageal, gastric, colonic and rectal carcinomas (Hardt et al, 2000; Schulze, 2000; Schneider and Schulze, 2003). Recently, we noticed that Tumour M2-PK can be detected and quantified in the faeces of patients with gastrointestinal cancer (Hardt et al, 2003). The present study describes the clinical utility of the determination of Tumour M2-PK in the stool of patients with colorectal cancer and control subjects without endoscopic evidence of colorectal neoplasms. 


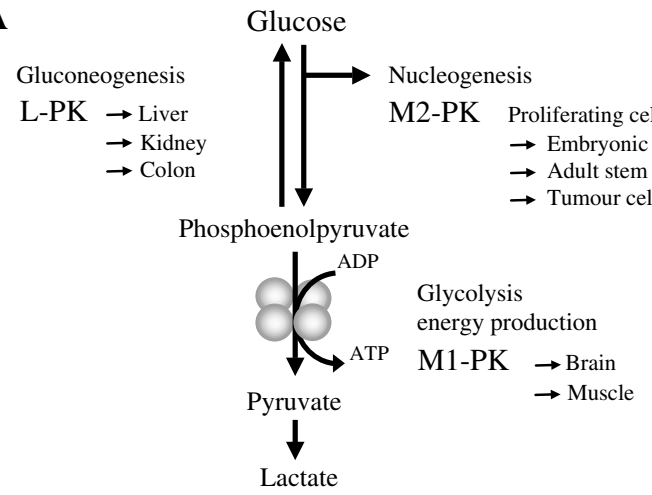

B

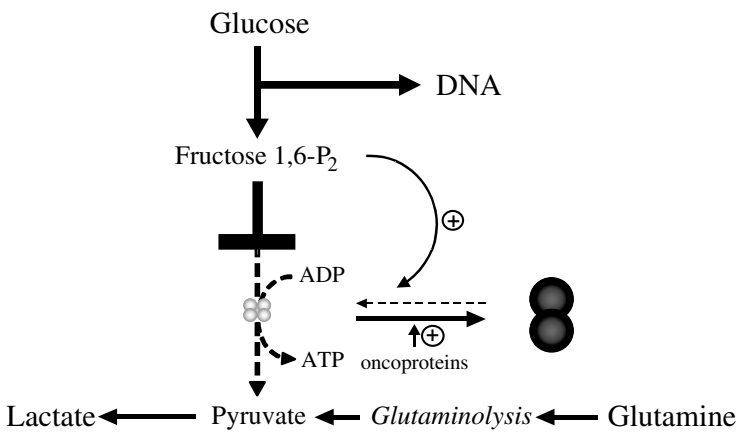

Figure I (A) Pyruvate kinase isoenzyme equipment of different tissues. (B) Metabolic consequences of the dimerisation of M2-PK.

\section{MATERIALS AND METHODS}

\section{Study protocol}

After obtaining informed consent, patients given appointments for colonoscopy for various reasons were asked to provide one stool sample for measuring faecal Tumour M2-PK. A short standard questionnaire about the patient's history was used to record clinical data. Stool samples of patients with colorectal cancer and patients without pathological findings were tested.

Endoscopies were carried out as standard investigations. Histology was obtained from the routine biopsies and/or from surgery. All data were collected prospectively and recorded on standardised forms. The study protocol was approved by the ethics committee of Giessen University Hospital.

\section{Measurement of faecal tumour M2-PK concentrations}

Tumour M2-PK was measured with a commercially available sandwich ELISA (ScheBo ${ }^{\circledR}$ Biotech AG, Giessen, Germany). For sample preparation, $100 \mathrm{mg}$ of the single, random stool specimen was extracted in $10 \mathrm{ml}$ extraction buffer and diluted $1: 10$ in the sample washing buffer provided. The ELISA plate is coated with a monoclonal antibody against Tumour M2-PK. Tumour M2-PK from stool samples or standards binds to the antibody. A second monoclonal antibody, which is biotinylated, binds to Tumour M2PK during the next incubation. Both monoclonal antibodies against Tumour M2-PK specifically react with Tumour M2-PK (dimeric form of $\mathrm{M} 2-\mathrm{PK}$ ) and do not crossreact with the other isoforms of pyruvate kinase (type $\mathrm{L}, \mathrm{R}, \mathrm{M} 1$ and tetrameric M2-PK). In the next incubation step, a conjugate of peroxidase (POD) and streptavidin binds to the biotin moiety. POD oxidises the substrate $3,3^{\prime}, 5,5^{\prime}$-tetra-methyl benzidine (TMB) and the oxidised form of TMB is determined photometrically at $450 \mathrm{~nm}$.

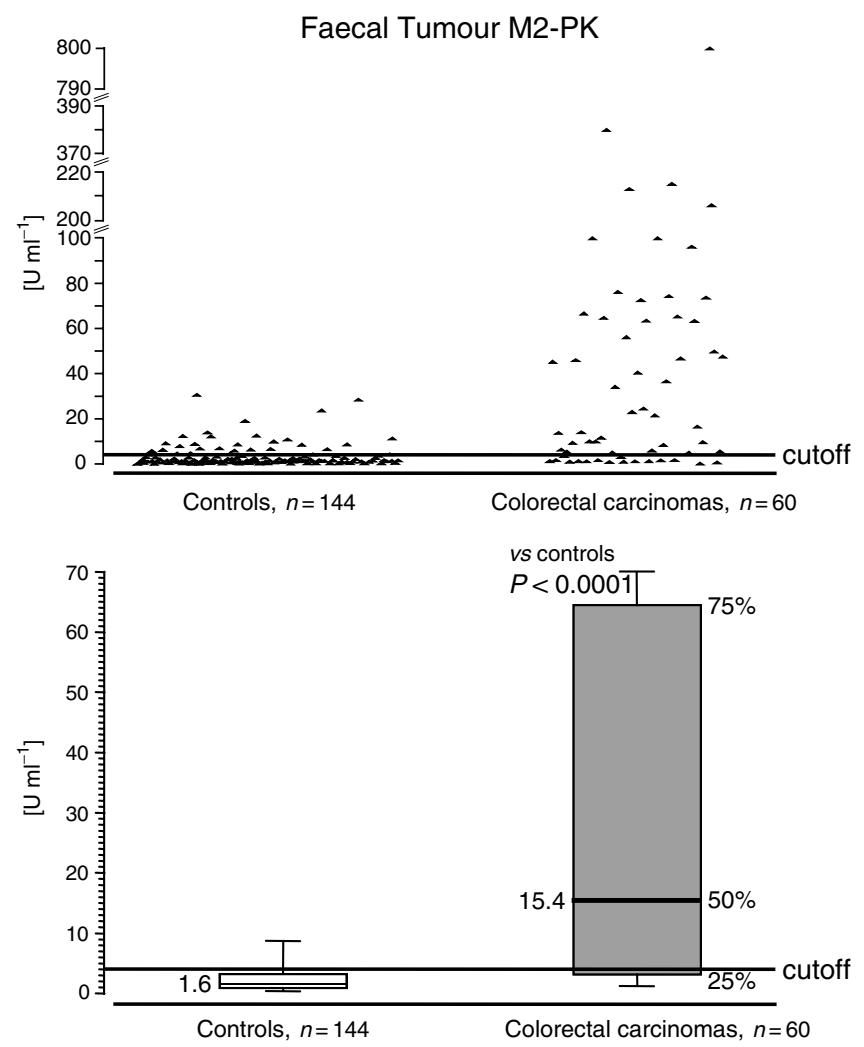

Figure 2 Tumour M2-PK levels in stool samples of patients with colorectal cancer and healthy control individuals. Sensitivity: 73\%; specificity: $78 \%$

\section{Statistical analysis}

For the statistical comparison of the nonparametrically distributed data, the Kruskall-Wallis ANOVA test was used (Statistica Version 5.0, StatSoft ${ }^{\circledR}$ Inc., Tulsa, USA).

Sensitivity was calculated as the number of patients with colorectal cancer who tested positive for Tumour M2-PK (true positives) divided by the total number of histologically confirmed tumour patients (true positives plus false negatives), expressed as a percentage (i.e. sensitivity $=$ (number of true positives/number of tumour patients) $\times 100$ ).

Specificity was calculated as the number of controls who tested negative for Tumour M2-PK (true negatives) divided by the total number of control subjects (true negatives plus false positives), expressed as a percentage (i.e. specificity $=$ (number of true negatives/number of patients without pathological findings at colonoscopy) $\times 100)$.

\section{RESULTS}

In all, 60 patients with colorectal cancer have been evaluated to date. A total of 144 patients underwent total colonoscopy without any pathological findings and served as controls. The range of faecal Tumour M2-PK levels is shown in Figure 2. There is a highly significant difference between tumour patients and controls. At a cutoff level of $4 \mathrm{U} \mathrm{ml}^{-1}$, the sensitivity was calculated to be $73 \%$ and the specificity as $78 \%$. TNM classification of the colorectal tumours according to the criteria of the American Joint Committee on Cancer (AJCC, 2002), as well as the Dukes' classification, revealed a strong correlation between the amount of faecal Tumour M2-PK and staging (Table 1; Figure 3). The sensitivities 
Table I Correlation between faecal tumour M2-PK levels and staging

\begin{tabular}{|c|c|c|c|c|c|}
\hline Classification & $n$ & $\begin{array}{l}\text { Median } \\
\left(\mathrm{U} \mathrm{ml}^{-1}\right)\end{array}$ & $\begin{array}{l}\text { Mean } \\
\left(\mathrm{U} \mathrm{ml}^{-1}\right)\end{array}$ & $\begin{array}{l}\text { s.e.m. } \\
\left(\mathbf{U} \mathrm{ml}^{-1}\right)\end{array}$ & $\begin{array}{l}\text { Range } \\
\left(\mathrm{U} \mathrm{ml}^{-1}\right)\end{array}$ \\
\hline Controls & 144 & 1.6 & 3,3 & 0.4 & $0.1-31$ \\
\hline TI & 7 & 5.5 & 11.1 & 5.9 & $1.3-45$ \\
\hline $\mathrm{T} 2$ & 11 & 10.0 & 23.8 & 9.9 & $1.1-100$ \\
\hline T3 & 33 & 34.2 & 55.5 & 13.7 & $1.0-380$ \\
\hline T4 & 9 & 47.8 & 132.7 & 86.2 & $0.2-800$ \\
\hline Dukes' A & 17 & 6.4 & 19.4 & 6.9 & $1.1-100$ \\
\hline Dukes' B & 16 & 14.5 & 31.5 & 8.5 & $1.0-100$ \\
\hline Dukes' C & 17 & 46.8 & 57.1 & 15.9 & $0.2-215$ \\
\hline Dukes' D & 10 & 36.4 & 156.2 & 81.1 & $0.7-800$ \\
\hline
\end{tabular}

TNM classification according to AJCC, 2000: TI: tumour invades submucosa; T2 tumour invades muscularis propria; T3: tumour invades through muscularis propria into subserosa or into nonperitonealised pericolic or perirectal tissues; T4: tumour directly invades other organs or structures and/or perforates visceral peritoneum. Dukes' staging according to Cuthbert Dukes, 1932: Dukes' A: the cancer confines to most superficial cell layers of colon and rectum; Dukes' B: the cancer penetrates the colon wall; Dukes' C: the cancer spreads to the lymph nodes; Dukes' D: the cancer spreads to distant organs. $n=$ number of individuals; s.e.m. $=$ standard error of the mean

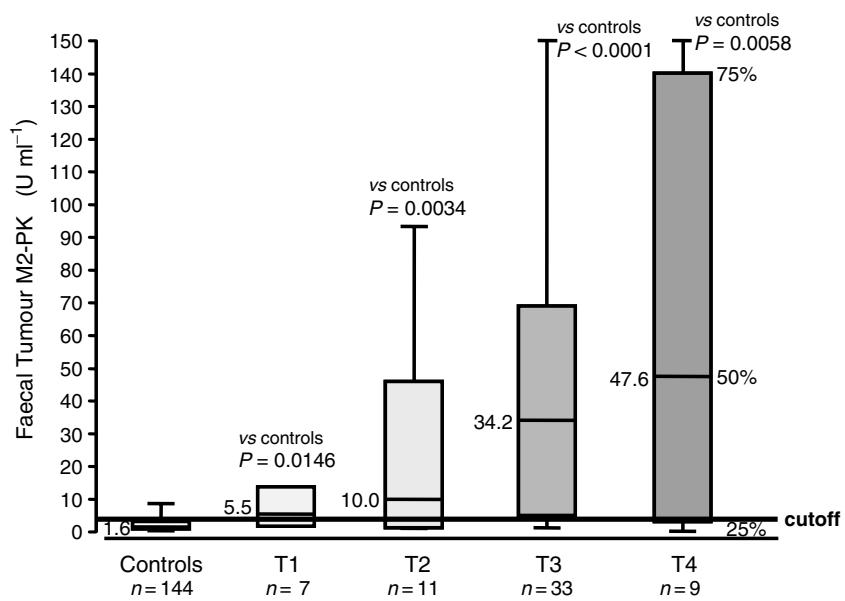

Figure 3 Correlation between faecal Tumour M2-PK levels and TNM staging. Sensitivities: TI, 57\%; T2, 64\%; T3, 78\%; and T4, 78\% (see Table I).

increased from 57 and $59 \%$ in the case of $\mathrm{T} 1$ and Dukes' A, respectively, to $78 \%$ in the case of T4 and $90 \%$ in the case of Dukes' D.

The intra-assay variance was evaluated by 18 -fold determination of five samples $\left(5-66 \mathrm{U} \mathrm{ml}^{-1}\right)$, giving an average coefficient of variance $(\mathrm{CV})$ of $7.9 \%(3.5-13.6 \%)$. The interassay variance was calculated with five samples between 4 and $73 \mathrm{U} \mathrm{ml}^{-1}$, tested on 10 different days. The average CV was $7.3 \%(3.8-12.6 \%)$.

\section{DISCUSSION}

In the present study, Tumour M2-PK was measured in the faeces of patients with colonoscopy-proven cancer of the colon and rectum. The data presented here are the results of the first extensive study in this field, which was conducted in secondary-care gastrointestinal clinics and reflects the current presentation of colorectal cancer in this setting.

The faecal levels of Tumour M2-PK are significantly higher in patients with colorectal cancer than in the control group without colorectal cancer (Figure 2). Overall sensitivity is $73 \%$ and specificity is $78 \%$. All patients in our study underwent complete colonoscopy to confirm (together with histology) colorectal cancer or exclude it. When similarly compared against colonoscopy, screening with a guaiac-based faecal occult blood test (FOBT) had a sensitivity of $24 \%$ in a recent study (Lieberman et al, 2001). Nevertheless, large randomised studies of screening with FOBT have demonstrated a reduction in mortality or risk of $15-33 \%$ (Hardcastle et al, 1996; Mandel et al, 1999; Jorgensen et al, 2002).

Owing to the high sensitivity, the determination of Tumour M2PK in stool samples might be a valuable new screening tool for colorectal cancer. Furthermore, a close correlation was found between Tumour M2-PK levels and tumour staging for both TNM and Dukes' classification (Table 1; Figure 3).

An increase of Tumour M2-PK levels has also been measured in EDTA-plasma samples of patients with colorectal cancer (Hardt et al, 2000; Schulze, 2000; Schneider and Schulze, 2003). The sensitivity of the Tumour M2-PK EDTA-plasma test was lower (nonmetastasising cancer: 48\%; metastasising cancer: 54\%) than the Tumour M2-PK stool test (Dukes' A: 59\%; Dukes' D: $90 \%$ ). Furthermore, Tumour M2-PK levels are also increased in EDTAplasma samples from patients with solid tumours at various sites, including renal, lung and breast cancers (Oremek et al, 1999; Wechsel et al, 1999; Lüftner et al, 2000; Schneider et al, 2000; Mazurek et al, 2002). Therefore, for the screening of colorectal cancer the determination of faecal Tumour M2-PK is superior to the EDTA-plasma test.

However, analogous to studies in breast, lung and kidney cancer patients (Wechsel et al, 1999; Lüftner et al, 2000; Hoopmann et al, 2002; Schneider et al, 2002), a possible field of application for the Tumour M2-PK EDTA-plasma test may be the monitoring and follow-up of patients with colorectal cancer.

Immunohistological staining of Tumour M2-PK in various rat and human tumours (breast, renal, lung, colon, rectal and skin tumours) revealed that increased Tumour M2-PK in tumour cells is a general metabolic alteration during tumorigenesis and correlated with malignancies of the tumours (Reinacher and Eigenbrodt, 1981; Bahnemann et al, 1990; Eigenbrodt et al, 1992; Schneider et al, 2000).

The upregulation of the M2-PK isoenzyme can be caused by mutations in the ras gene and upregulation of HIF-1 (Kress et al, 1998; Mazurek et al, 2001). HIF-1 is stabilised by p53 mutations (Kress et al, 1998; Ravi et al, 2000). Indeed, mutations in the ras oncogene and p53 antioncogene are detectable in $40-60 \%$ of colorectal cancers (Bos, 1989; Kinzler and Vogelstein, 1996; Dong et al, 2001; Rengucci et al, 2001; Nishikawa et al, 2002; Smith et al, 2002).

The determination of mutated oncogenes and antioncogenes in stool samples has the advantage of high specificity. For example, mutations of K-ras, p53 or within the adenomatous polyposis coli (APC) gene were not detected in any stool samples of healthy controls (Rengucci et al, 2001; Nishikawa et al, 2002; Traverso et al, 2002). However, due to the genetic heterogeneity within colorectal cancer, a multitarget assay panel (e.g. mutations of k-ras, p53 and APC genes, as well as Bat-26 (a microsatellite instability marker) and highly amplifiable 'long' DNA) has to be screened to reach high sensitivities (63-95\%) (Ahlquist et al, 2000; Tagore et al, 2003).

Since M2-PK is a direct target of several oncoproteins, the determination of faecal Tumour M2-PK might be more sensitive than the detection of mutations in the oncoproteins and antioncoproteins themselves.

In contrast to many other genes, no mutations have yet been found in the M2-PK gene (http://www.pubmed.gov: nucleotide, tumour pyruvate kinase type M2). Furthermore, the overexpression of a mutated M2-PK protein suppresses A-Raf transformation in NIH 3T3 cells, which underlines the central role of M2-PK within the tumour metabolome (Le Mellay et al, 2002). Indeed, pyruvate kinase controls the exit of glycolysis and is responsible for net ATP production of this pathway, especially under hypoxic 
conditions. M2-PK can switch between a highly active tetrameric form with a high affinity to its substrate, phosphoenolpyruvate (PEP), and a nearly inactive dimeric form with a low PEP affinity (Figure 1B). The tetramer: dimer ratio of M2-PK is regulated by oncoproteins and metabolic intermediates, such as fructose 1,6-P2 and serine, and determines whether glucose carbons are converted to pyruvate and lactate under the production of energy (tetrameric form) or are channelled into synthetic processes, such as DNA, phospholipid and amino-acid synthesis (dimeric form) (Mazurek et al, 1997; Griffiths et al, 2002; Boren et al, 2003). When M2-PK is mainly in the nearly inactive dimeric form (Tumour M2-PK) energy is provided by the degradation of the amino-acid glutamine to lactate, which has been termed glutaminolysis (Figure 1B) (http://www.metabolic-database.com).

\section{REFERENCES}

Ahlquist DA, Skoletsky JE, Boynton KA, Harrington JJ, Mahoney DW, Pierceall WE, Thibodeau SN, Shuber AP (2000) Colorectal cancer screening by detection of altered human DNA in stool: feasibility of a multitarget assay panel. Gastroenterology 119: 1219-1227

American Joint Committee on Cancer (2002) Colon and Rectum. In AJCC Cancer Staging Manual, Greene FL, Page DL, Fleming ID, Fritz A, Balch CM, Haller DG, Morrow M (eds). 6th edn. pp 113-124, New York, NY: Springer

Atsumi T, Chesney J, Metz C, Leng L, Donnelly S, Makita Z, Mitchell R, Bucala R (2002) High expression of inducible 6-phosphofructo-2-kinase/ fructose-2,6-bisphosphatase (iPFK-2; PFKFB3) in human cancers. Cancer Res 62(20): $5881-5887$

Bahnemann R, Domingo M, Eigenbrodt E, Reinacher M (1990) Immunohistologic photometric quantification of pyruvate kinase content of rat tumors. Verh Dtsch Ges Pathol 74: 373-375

Birkenkamp-Demtroder K, Christensen LL, Harder Olesen S, Frederiksen CM, Lahio P, Aaltonen LA, Laurberg S, Sørensen FB, Hagemann R, rntoft TF (2002) Gene expression in colorectal cancer. Cancer Res 62: $4352-$ 4363

Bolen JB, Veillette A, Schwartz AM, DeSeau V, Rosen N (1987) Activation of pp60c-src protein kinase activity in human colon carcinoma. Proc Natl Acad Sci USA 84: 2251-2255

Boren J, Lee WN, Bassilian S, Centelles JJ, Lim S, Ahmed S, Boros L, Cascante M (2003) The stable isotope-based dynamic metabolic profile of butyrate induced HT29 cell differentiation. J Biol Chem 278: $28395-28402$

Bos JL (1989) Ras oncogenes in human cancer: a review. Cancer Res 49: $4682-4689$

Cerwenka H, Aigner $\mathrm{R}$, Bacher $\mathrm{H}$, Werkgartner $\mathrm{G}$, El-Shabrawi A, Quehenberger F, Mischinger HJ (1999) TUM2-PK (pyruvate kinase type tumor M2), CA19-9 and CEA in patients with benign, malignant and metastasizing pancreatic lesions. Anticancer Res 19: 849-852

Dehm S, Senger MA, Bonham K (2001) SRC transcriptional activation in a subset of human colon cancer cell lines. FEBS Lett 487(3): 367-371

Dhillon AS, Meikle S, Peyssonnaux C, Grindlay J, Kaiser C, Steen H, Shaw PE, Mischak H, Eychene A, Kolch W (2003) A Raf-1 mutant that dissociates MEK/extracellular signal-regulated kinase activation from malignant transformation and differentiation but not proliferation. $\mathrm{Mol}$ Cell Biol 23(6): 1983-1993

Dong SM, Traverso G, Johnson C, Geng L, Favis R, Boynton K, Hibi K, Goodman SN, D'Allessio M, Paty P, Hamilton SR, Sidransky D, Barany F, Levin B, Shuber A, Kinzler KW, Vogelstein B, Jen J (2001) Detecting colorectal cancer in stool with the use of multiple genetic targets. J Natl Cancer Inst 93: 858-865

Durany N, Joseph J, Campo E, Molina R, Carreras J (1997) Phosphoglycerate mutase, 2,3-bisphosphoglycerate phosphatase and enolase activity and isoenzymes in lung, colon and liver carcinomas. $\mathrm{Br} J$ Cancer 75(7): 969-977

Eigenbrodt E, Basenau D, Holthusen S, Mazurek S, Fischer G (1997) Quantification of tumor type M2 pyruvate kinase (Tu M2-PK) in human carcinomas. Anticancer Res 17: 3153-3156

Eigenbrodt E, Kallinowski F, Ott M, Mazurek S, Vaupel P (1998a) Pyruvate kinase and the interaction of amino acid and carbohydrate metabolism in solid tumors. Anticancer Res 18: 3267-3274
The oscillation between the highly active tetrameric form and the nearly inactive dimeric form allows optimal adaptation of the tumour metabolome to the varying nutrient and oxygen supply constantly found in solid tumours (Eigenbrodt et al, 1998a; Vaupel et al, 2003).

Tumour M2-PK is detected with an ELISA that can be easily performed in every routine laboratory. Samples are stable and the sensitivity of the Tumour M2-PK test is higher than the detection of mutations in p53, ras or APC (Rengucci et al, 2001; Nishikawa et al, 2002; Traverso et al, 2002). Therefore, the detection of Tumour M2-PK levels in the stool might provide an interesting screening tool for colorectal cancer. To further validate this new test in a larger cohort, a larger cross-sectional study will be performed in the future.

Eigenbrodt E, Mazurek S, Friis R (1998b) Double role of pyruvate kinase type M2 in the regulation of phosphometabolite pools. In Cell Growth and Oncogenesis, Bannasch P, Kanduc D, Papa S, Tager JM (eds) pp 15-30, Basel: Birkhäuser Verlag

Eigenbrodt E, Reinacher M, Scheefers-Borchel U, Scheefers H, Friis R (1992) Double role for pyruvate kinase type M2 in expansion of phosphometabolite pools found in tumor cells. Crit Rev Oncogen 3: $91-115$

Griffiths JR, McSheehy PM, Robinson SP, Troy H, Chung YL, Leek RD, Williams KJ, Stratford IJ, Harris AL, Stubbs M (2002) Metabolic changes detected by in vivo magnetic resonance studies of HEPA-1 wild type tumors and tumors deficient in hypoxia-inducible factor-1beta (HIF1beta): evidence of an anabolic role for the HIF-1 pathway. Cancer Res 62: $688-695$

Hardcastle JD, Chamberlain JO, Robinson MHE, Moss SM, Amar SS, Balfour TW, James PD, Mangham CM (1996) Randomized, controlled trial of faecal occult blood screening for colorectal cancer. Lancet 348: $1472-1477$

Hardt PD, Ngoumou BK, Rupp J, Schnell-Kretschmer H, Kloer HU (2000) Tumor M2-pyruvate kinase: a promising tumor marker in the diagnosis of gastro-intestinal cancer. Anticancer Res 20: 4965-4968

Hardt PD, Toepler M, Ngoumou B, Rupp J, Kloer HU (2003) Measurement of fecal pyruvate kinase type M2 (Tumor M2-PK) concentrations in patients with gastric cancer, colorectal cancer, colorectal adenomas and controls. Anticancer Res 23: 851-854

Hegde P, Qi R, Gaspard R, Abernathy K, Dharap S, Earle-Hughes J, Gay C, Nwokekeh NU, Chen T, Saeed AI, Sharov V, Lee NH, Yeatman J, Quackenbusch J (2001) Identification of tumor markers in models of human colorectal cancer using a 19,200-element complementary DNA microarray. Cancer Res 61: 7792-7797

Hoopmann M, Warm M, Mallmann P, Thomas A, Gohring UJ, Schöndorf T (2002) Tumor M2 pyruvate kinase - determination in breast cancer patients receiving trastuzumab therapy. Cancer Lett 187: 223-228

Iravani S, Mao W, Fu L, Karl R, Yeatman T, Jove R, Coppola D (1998) Elevated c-Src protein expression is an early event in colonic neoplasia. Lab Invest 78: $365-371$

Irby RB, Mao W, Coppola D, Kang J, Loubeau JM, Trudeau W, Kar R, Fujita DJ, Jove R, Yeatman TJ (1999) Activating SRC mutation in a subset of advanced human colon cancers. Nat Genet 21: 187-190

Jorgensen OD, Kronborg O, Fenger C (2002) A randomized study of screening for colorectal cancer using faecal occult blood testing: results after 13 years and seven biennial screening rounds. Gut 50: 29-32

Kinzler KW, Vogelstein B (1996) Lessons from hereditary colorectal cancer. Cell 87: $159-170$

Kress S, Stein A, Maurer P, Weber B, Reichert J, Buchmann A, Huppert P, Schwarz M (1998) Expression of hypoxia-inducible genes in tumor cells. $J$ Cancer Res Clin Oncol 124(6): 315-320

Le Mellay V, Houben R, Troppmair J, Hagemann C, Mazurek S, Frey U, Beigel J, Weber CM, Benz R, Eigenbrodt E, Rapp U (2002) Regulation of glycolysis by Raf protein serine/threonine kinases. Adv Enzyme Regul 42: $317-332$

Lieberman DA, Harford WV, Ahnen DJ, Provenzale D, Sontag SJ, Schnell TG, Chejfec G, Campbell DR, Durbin TE, Bond JH, Nelson DB, Ewing SL, Triadafilopoulos G, Ramirez FC, Lee JG, Collins JF, Fennerty MB, 
Johnston TK, Corless CL, McQuaid KR, Garewal H, Sampliner RE, Morales TG, Fass R, Smith RE, Maheshwari Y, Weiss DG, for the Veterans Affairs Cooperative Study Group 380 (2001) One-time screening for colorectal cancer with combined fecal occult-blood testing and examination of the distal colon. $N$ Engl J Med 345: 555-560

Luckett JC, Huser MB, Giagtzoglou N, Brown JE, Pritchard CA (2000) Expression of the A-raf proto-oncogene in the normal adult and embryonic mouse. Cell Growth Differ 11: 163-171

Lüftner D, Mesterharm J, Akrivakis C, Geppert R, Petrides PE, Wernecke $\mathrm{KD}$, Possinger K (2000) Tumor type M2 pyruvate kinase expression in advanced breast cancer. Anticancer Res 20: 5077-5082

Mandel J, Church TR, Ederer F, Bond JH (1999) Effectiveness of biennial screening for fecal occult blood. J Natl Cancer Inst 91: 434-437

Mazurek S, Boschek CB, Eigenbrodt E (1997) The role of phosphometabolites in cell proliferation, energy metabolism, and tumor formation. Bioenerg Biomembr 29: 315-330

Mazurek S, Eigenbrodt E (2003) The tumor metabolome. Anticancer Res 23: $1149-1154$

Mazurek S, Grimm H, Oehmke M, Weisse G, Teigelkamp S, Eigenbrodt E (2000) Tumor M2-PK and glutaminolytic enzymes in the metabolic shift of tumor cells. Anticancer Res 20: 5151-5154

Mazurek S, Lüftner D, Wechsel HW, Schneider J, Eigenbrodt E (2002) Tumor M2-PK: a marker of the tumor metabolome. In Tumor Markers Physiology, Pathobiology, Technology, and Clinical Application, Diamandis EP, Fritsche HA, Lilja H, Chan DW, Schwartz MK (eds) pp 471-475, Washington, DC: AACC Press

Mazurek S, Zwerschke W, Jansen-Dürr P, Eigenbrodt E (2001) Metabolic cooperation between different oncogenes during cell transformation: interaction between activated ras and HPV-16 E7. Oncogene 20: $6891-6898$

Nishikawa T, Maemura K, Hirata I, Matsuse R, Morikawa H, Toshin K, Murano M, Hashimoto K, Nakagawa Y, Saitoh O, Uchida K, Katsu K (2002) A simple method of detecting K-ras point mutations in stool samples for colorectal cancer screening using one-step polymerase chain reaction/restriction fragment length polymorphism analysis. Clin Chim Acta 318: $107-112$

Oremek GM, Teigelkamp S, Kramer W, Eigenbrodt E, Usadel KH (1999) The pyruvate kinase isoenzyme tumor M2-PK (Tu M2-PK) as a tumor marker for renal carcinoma. Anticancer Res 19: 2599-2602

Ravi R, Mookerjee B, Bhujwalla ZM, Sutter CH, Artemov D, Zeng Q, Dillehay LE, Madan A, Semenza GL, Bedi A (2000) Regulation of tumor angiogenesis by $\mathrm{p} 53$-induced degradation of hypoxia-inducible factor 1alpha. Genes Dev 14(1): $34-44$

Reinacher M, Eigenbrodt E (1981) Immunohistological demonstration of the same type of pyruvate kinase isoenzyme (M2-PK) in tumors of chicken and rat. Virchows Arch B 37: 79-88

Rengucci C, Maiolo P, Saragoni L, Zoli W, Amadori D, Calistri D (2001) Multiple detection of genetic alterations in tumors and stool. Clin Cancer Res 7: $590-593$

Saheki S, Harada K, Sanno Y, Tanaka T (1978) Hybrid isozymes of rat pyruvate kinase. Their subunit structure and developmental changes in the liver. Biochim Biophys Acta 526(1): 116-128
Saheki S, Saheki K, Tanaka T (1979) Changes in pyruvate kinase isoenzymes of rat small intestine during development and the synergistic effect on them of thyroid and glucocorticoid hormones. Enzyme 24(1): $8-17$

Schneider J, Morr H, Velcovsky HG, Weisse G, Eigenbrodt E (2000) Quantitative detection of Tumor M2-pyruvate kinase in plasma of patients with lung cancer in comparison to other lung diseases. Cancer Detect Prev 24: $531-535$

Schneider J, Neu K, Grimm H, Velcovsky HG, Weisse G, Eigenbrodt E (2002) Tumor M2-pyruvate kinase in lung cancer patients: immunohistochemical detection and disease monitoring. Anticancer Res 22: $311-318$

Schneider J, Schulze G (2003) Comparison of Tumor M2-pyruvate kinase (Tumor M2-PK), carcinoembryonic antigen (CEA), carbohydrate antigens CA 19-9 and CA 72-4 in the diagnosis of gastrointestinal cancer. Anticancer Res 23: 5089-5094

Schulze G (2000) The tumor marker Tumor M2-PK: an application in the diagnosis of gastrointestinal cancer. Anticancer Res 20: 4961-4964

Smith G, Carey FA, Beattie J, Wilkie MJ, Lightfoot TJ, Coxhead J, Garner RC, Steele RJ, Wolf CR (2002) Mutations in APC, Kirsten-ras, and p53alternative genetic pathways to colorectal cancer. Proc Natl Acad Sci USA 99: $9433-9438$

Staal GEJ, Rijksen G (1991) Pyruvate kinase in selected human tumors. In Biochemical and Molecular Aspects of Selected Cancers, Pretlow TG, Prelow TP (eds) pp 313-337, San Diego: Academic Press

Steinberg P, Klingelhöffer A, Schäfer A, Wüst G, Weisse G, Oesch F, Eigenbrodt E (1999) Expression of pyruvate kinase M2 in preneoplastic hepatic foci of $\mathrm{N}$-nitrosomorpholine-treated rats. Virchows Arch 434: $213-220$

Tagore KS, Lawson MJ, Yucaitis JA, Gage R, Orr T, Shuber AP, Ross ME (2003) Sensitivity and specificity of a stool DNA multitarget assay panel for the detection of advanced colorectal neoplasia. Clin Colorectal Cancer 3: $47-53$

Traverso G, Shuber A, Levin B, Johnson C, Olsson L, Schoetz Jr DJ, Hamilton SR, Boynton K, Kinzler KW, Vogelstein B (2002) Detection of APC mutations in faecal DNA from patients with colorectal tumors. $N$ Engl J Med 346: $311-320$

Vaupel P, Thews O, Kelleher DK, Konerding MA (2003) O2 extraction is a key parameter determining the oxygenation status of malignant tumors and normal tissues. Int J Oncol 22: 795-798

Wechsel HW, Petri E, Bichler KH, Feil G (1999) Marker for renal cell carcinoma (RCC): the dimeric form of pyruvate kinase type M2 (Tu M2PK). Anticancer Res 19: 2583-2590

Williams NS, Gaynor RB, Scoggin S, Verma U, Gokaslan T, Simmang C, Fleming J, Tavana D, Frenkel E, Becerra C (2003) Identification and validation of genes involved in the pathogenesis of colorectal cancer using cDNA microarrays and RNA interference. Clin Cancer Res 9: 931-946

Zwerschke W, Mazurek S, Massimi P, Banks L, Eigenbrodt E, Jansen-Dürr P (1999) Modulation of pyruvate kinase type M2 by the human papillomavirus type 16 E7 oncoprotein. Proc Natl Acad Sci USA 96: $1291-1296$ 